\title{
Historické mapy v prostředí mapového serveru
}

\author{
Jiří Cajthaml \\ Department of Mapping and Cartography \\ Faculty of Civil Engineering, CTU in Prague \\ E-mail: jiri.cajthaml@fsv.cvut.cz
}

\begin{abstract}
Abstrakt
Tento př́spěvek se zabývá možnostmi zobrazování historických map na internetu. Tyto mapy často leži $v$ archivech, kde jsou pro běžné uživatele těžko př́stupné. V souvislosti s rozvojem informačních technologii docházi nyni $k$ převodu map do digitální podoby a jejich archivaci na digitálních médiich. Současná techniologie jde však ještě dál. Data mohou být publikována na internetu. Tam mohou být velice jednoduše $k$ dispozici všem, jak odbornikưm tak laikưm. Kromě toho, že mohou být data na internetu prohližena, s nástupem webových služeb je nyní možné data distribuovat mezi různými aplikacemi. Webové mapové služby jsou budoucností webové kartografie. Muij konkrétni ukázkový projekt souvisí s daty II. vojenského mapování Rakouska-Uherska (1819-1858). Tato data jsem publikoval pomocí mapového serveru na internetu. Data jsou volně př́stupná a to nejen pro prohlížení, ale jsou i distribuována pomocí služby WMS.
\end{abstract}

\section{Zdroj digitálních dat - skenování map}

Analogové mapy je nutné převést do digitální formy skenováním. Skenování je založeno na principu snímání obrazových elementů, zpravidla ve třech barevných složkách (systém barev RGB). Při skenování vystupují dvě velice důležité konstanty - hustota skenování a barevná hloubka. V Laboratoři digitální kartografie na Stavební fakultě, ČVUT v Praze jsem provedl raadu pokusných skenování s různou hustotou i barevnou hloubkou. K dispozici zde máme bubnový velkoformátový skener Contex Chameleon Tx36.

Hustota skenování je často udávána v jednotkách dpi (dot per inch, bodů na palec). Pro skenování map se jeví nejvhodnější hodnota někde mezi 300dpi a 500dpi. Při vyšší hustotě skenování již nedochází k výraznému vylepšení obrazu, pod 300dpi dochází často k degradaci textů na mapách. Konkrétní nejvhodnější hustota ale vždy závisí na konkrétní mapě (velikost písma, čitelnost mapy,...).

Barevná hloubka velice významně ovlivňuje kvalitu digitálního obrazu. Pro skenování barevných map jsou nejpoužívanější dvě metody: 8-bitové snímání do barevné palety nebo 24bitové snímání pro složky RGB (tzv. "true color"). Méně často se používá 16-bitové snímání, kde zelené složce odpovídá 6 bitů, modré a červené pak po 5 bitech. Skenování do 8-bitové palety znamená, že výsledný obraz bude složen pouze z 256 barev (28 bitů). Většinou toto skenování probíhá dvoufázově. Skener otestuje mapu a zvolí 256 barev palety. Poté je každému snímanému bodu přiřazena nejbližší hodnota z palety. Výhodou tohoto snímání je úspora velikosti dat (třetinová velikost oproti "true color"). 24-bitové snímání představuje kvalitnější možnost, kde každému obrazovému elementu (pixelu) je možné přiřadit jednu z přibližně 16,7 
milónu barev (24 bitů). Skenování v této barevné hloubce se hodí zvláště tam, kde bude následně použita JPEG komprese dat. Ta totiž využívá právě "true color".

Pokud jde o mapy II. vojenského mapování, které jsem používal, ty byly neskenovány přímo ve vídeňském státním archivu pro Ministerstvo životního prostředí $\mathrm{CLR}^{1}$. S těmito daty pak v ČR pracuje Laboratoř geoinformatiky UJEP v Mostě ${ }^{2}$. S tímto pracovištěm spolupracujeme na katedře mapování a kartografie. Mapy byly ve Vídni neskenovány s hloubkou 400dpi a v 8-bitové paletě. Sám jsem tedy nemohl ovlivnit parametry skenování. Sám bych raději navrhoval skenování v "true color" a případnou kompresi dat. Skenování v 8 bitech bylo provedeno patrně kvůli úspoře místa na datových médiích. Hustota skenování 400dpi je podle mě ideální.

\section{Komprese dat}

Po vlastním neskenování je možné data zkomprimovat tak, aby se zmenšila celková velikost souboru. Rozlišujeme 2 základní typy komprese - bezeztrátovou a ztrátovou. Při bezeztrátové kompresi můžeme zpětným postupem získat opět originální obraz, při ztrátové nikoliv. Teorii kompresních algoritmů zde patrně nemá smysl popisovat. Pro konkrétní data II. vojenského mapování byla použita bezeztrátová komprese LZW. Zároveň byla na zkoušku data převedena do "true color" obrazu s JPEG kompresí. Touto ztrátovou kompresí sice obraz degradujeme, nicméně ušetříme velké množství místa a dále zvýšíme rychlost aplikace, která bude s daty pracovat. Naskenovaná data by měla zůstat nedegradovaná v archivu, pro práci v aplikaci však doporučuji kompresi použít.

\section{Georeferencování}

Data historických vojenských mapování představují listy jednotlivých mapových sekcí. Každý mapový list obsahuje kromě mapového pole také mapový rám, nadpis a další mimorámové údaje. Pokud chceme pracovat s bezešvou mapou na území celé ČR, je nutné před samotným georeferencováním rastry ořezat podle mapových rámů.

Georeferencování představuje umístění rastrového obrazu do souřadnicového systému. Rastrový soubor může nést informaci o své poloze bud' př́imo v datech (zpravidla v hlavičce souboru) nebo v externím souboru. První skupinu nejčastěji reprezentuje formát GeoTiff, druhou skupinu pak tzv. "world files". Formát GeoTiff je tvořen jediným souborem (TIF), který obsahuje v hlavičce zároveň informaci o poloze rastru. "World files" jsou malé textové soubory, které doprovázejí daný rastr. Data jsou pak tvořena vždy dvojicí souborů (TIF+TFW, JPEG+JGW,...). Souřadnicové umístění je dáno 6 parametry (souřadnice $\mathrm{x}$ a y středu levého horního pixelu, velikost pixelů $\mathrm{v}$ osách $\mathrm{x}$ a $\mathrm{y}$, stočení osy $\mathrm{x}$ a y). Tyto parametry vlastně představují afinní transformaci rastru. Rotace v osách bývá zpravidla nulová, nebot práce s natočenými rastry je daleko náročnější. Proto jsou data při georeferencování přeukládána do nového rastru s pixely ve směru souřadnicových os.

V mém př́padě byly vytvořeny 2 sady georeferencovaných dat II. vojenského mapování z území Čech. První soubor vznikl ve spolupráci s Ing. Brůnou (Laboratoř geoinformatiky

\footnotetext{
${ }^{1}$ http: //www.env.cz

${ }^{2}$ http: //www.geolab.cz
} 
UJEP v Mostě ${ }^{3}$ ) a představuje rastry (TIF s LZW kompresí) s hustotou 200dpi. Tato data byla georeferencována v software ArcGIS 9.0. Druhý soubor byl vytvořen ve spolupráci s Ing. Doubravou (GEPRO, a.s. ${ }^{4}$ ) a představuje rastry (JPEG komprimované) s hustotou 400dpi. Tato data bylo georeferencována $\mathrm{v}$ software Kokeš. $\mathrm{V}$ obou př́padech byla použita metoda "world files".

Samotné georeferencování probíhalo v obou případech afinní transformací na rohy mapových listů. Souřadnice rohů mapových listů byly ze systému Stabilního katastru (Gusterberg) převedeny do systému S-JTSK doc. Čadou (ZČU Plzeň ${ }^{5}$ ), který odvodil globální transformační klíč. Jak vyplývá z disertační práce Ing. Doubravy [5], přesnějšś georeferencování u těchto map nemá smysl. Odchylky transformovaných bodů (globální klíč versus afinní transformace na rohy mapových listů) dosahují v maximálních hodnotách pouze několika metrů.

\section{Mapový server}

V obecnějším pojetí lze mapový server chápat jako celou internetovou aplikaci, která slouží k práci s prostorovými daty. V užším pojetí mapovým serverem rozumíme aplikaci, která umí zpracovat požadavky uživatele a je schopná vrátit určitý výřez zdrojových dat. Dále budu pracovat s pojmem mapový server v užším vymezení.

Existuje celá řada již naprogramovaných mapových serverů. Některé jsou komerční, některé svobodné (volně šiřitelné). Každý odborník si navíc může naprogramovat vlastní mapový server podle jeho představ. Já jsem využil již existující řešení, konkrétně UMN MapServer6 který patří do kategorie svobodného software. UMN MapServer ${ }^{7}$ může pracovat v prostředí internetu bud' pomocí rozhraní CGI nebo využitím knihovny MapScript (lze ji použít v řadě programovacích jazyků - PHP, Python, Perl). Já jsem se rozhodl pro použití CGI MapServeru, ačkoliv bych rád v budoucnu vyzkoušel i možnosti MapScriptu. Mapový server ve výsledné aplikaci generuje obrázky map (hlavní mapové okno, referenční mapka), obrázek grafického měřítka, atd. Všechny tyto obrázky jsou generovány po odeslání požadavku uživatele (kliknutí na ikonu, zaškrtnutí políčka, posun mapy, atd.). Mapový server je tedy jakýmsi jádrem aplikace, která umí pracovat se zdrojovými daty v souřadnicovém systému a umí generovat obrázky do internetové stránky. Více o teorii fungování mapových serverů lze nalézt v mých publikacích na 16. Kartografické konferenci v Brně [1], GIS Ostrava 2006 [2], nebo na Juniorstavu 2006 [3].

\section{Internetová aplikace}

Vlastním uživatelským rozhraním mapové aplikace je XHTML stránka. Existuje více možností jak je stránka vytvářena. První, jednodušší možností je využít šablonový systém UMN MapServeru ${ }^{8}$, který umožňuje do stránky přímo vkládat objekty vygenerované MapServerem. Tímto způsobem byla vytvořena jedna z ukázkových aplikací. Celá internetová stránka je

\footnotetext{
${ }^{3}$ http: //www.geolab.cz

${ }^{4}$ http://www.gepro.cz

${ }^{5}$ http://gis.zcu.cz

${ }^{6}$ http: //mapserver.gis.umn.edu

${ }^{7}$ http://mapserver.gis.umn.edu

${ }^{8}$ http://mapserver.gis.umn.edu
} 
pak HTML formulářem po jehož odeslání dojde k novému vygenerování všech mapových obrázků. Ovládání mapy je vyřešeno pomocí tlačítek a přepínacích políček. Ukázka aplikace je na obrázku č.1.

Ukázka mapového serveru - listy II.VM, Čechy

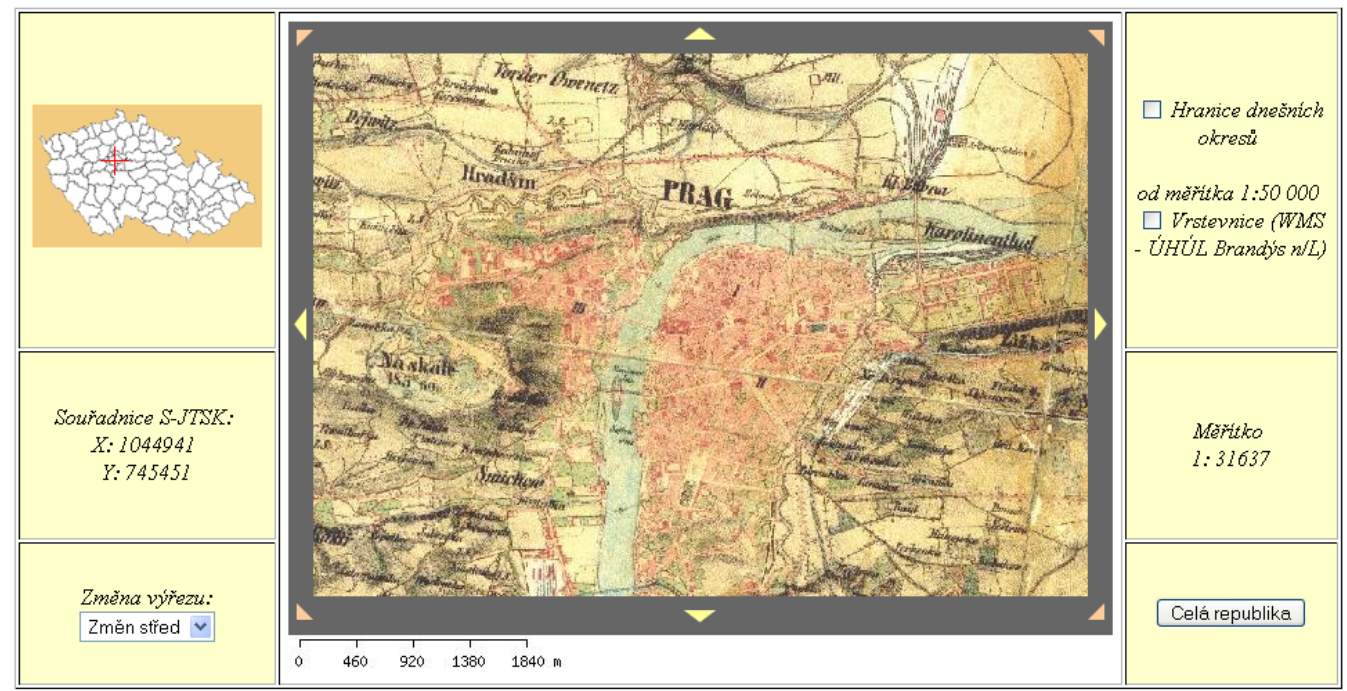

Obrázek č.1: CGI MapServer

Druhá ukázková aplikace využívá nové možnosti JavaScriptu (programovací jazyk pracující v internetových prohlížečích). Je zde využita metoda AJAX (Asynchronous JavaScript And XML), konkrétně v použité knihovně mscross. Díky této knihovně, která opět patří do skupiny svobodného software, je možné mapu ovládat mnohem interaktivněji (změna výřezu mapy taženým obdélníkem, posun mapy tažením). Některé ovládací prvky zůstávají stejné jako v předchozím případě.

Některé další doplňkové funkce jsem doprogramoval. Jde zejména o odečítání kartografických souřadnic při pohybu myši nad mapou a dále o vyhledávání obcí v rámci ČR. Odečítání souřadnic je řešeno JavaScriptovými funkcemi, bohužel odděleně pro různé internetové prohlížeče (Internet Explorer má nestandardní chování). Vyhledávání obcí je pak založeno na spojení AJAX (výpis obcí po zadávání jednotlivých písmen) a PHP (obsloužení databázového požadavku). Aplikace využívá databázi ÚIR-ZSJ, kterou je možné získat z webu Českého statistického úřadu. Na serveru byla data migrována do volně šiřitelné databáze PostgreSQL ${ }^{9}$. Ukázka aplikace je na obrázku č.2.

\section{Webové mapové služby}

Pomocí webových mapových služeb je možné poskytovat data jiným aplikacím, př́ípadně připojovat data $\mathrm{z}$ ostatních serverů. UMN MapServer ${ }^{10}$ podporuje webové mapové služby velmi dobře a proto není problémem připojit data z jiných serverů, případně data publikovat

\footnotetext{
${ }^{9}$ http: //www.postgresql .org

${ }^{10}$ http://mapserver.gis.umn.edu
} 


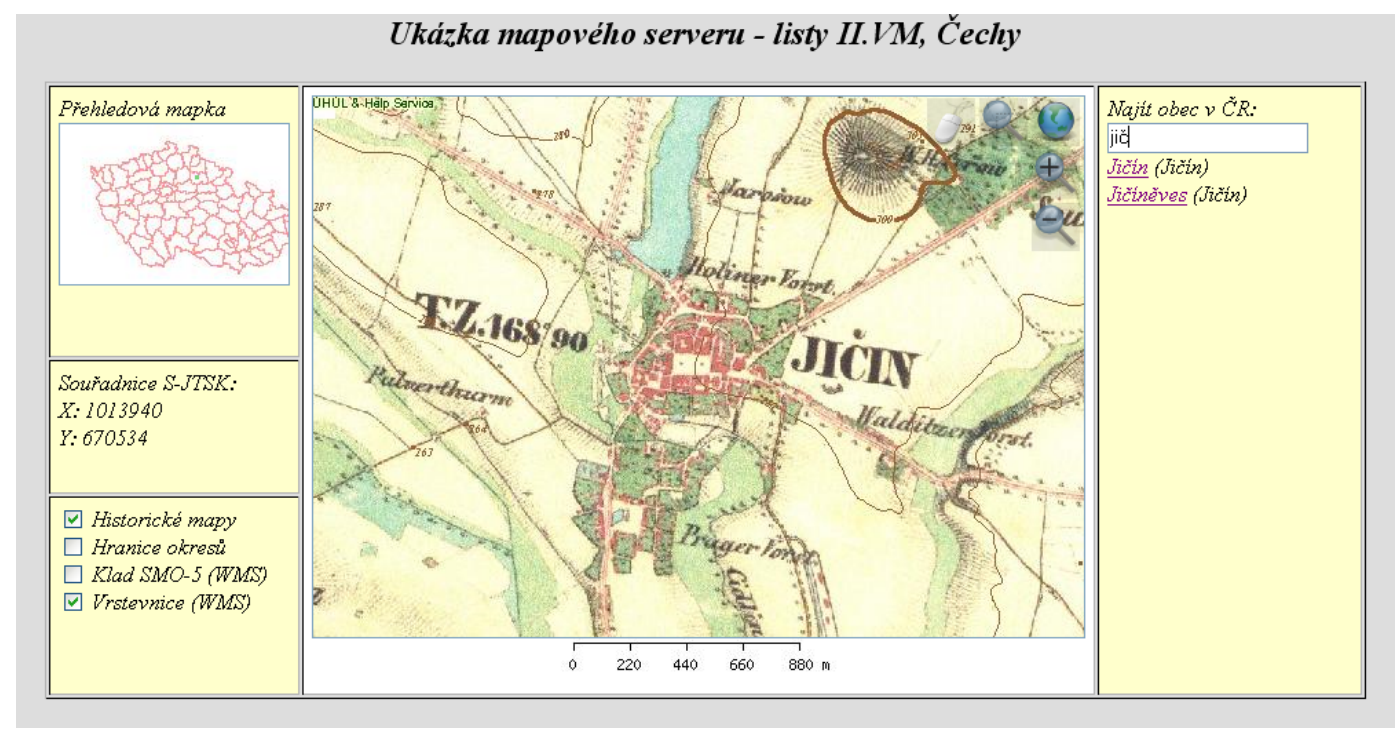

Obrázek č.2: CGI MapServer + AJAX

pomocí mapových služeb. Vzhledem k tomu, že historické mapy představují rastrová data, má smysl použít pouze službu WMS.

V mých aplikacích jsou na ukázku připojena některá data z datového skladu ÚHÚL Brandýs nad Labem. Jedná se o vrstevnice a klad map SMO-5. Není problémem připojit libovolné další vrstvy. Zároveň jsou pomocí WMS služby distribuována data II. vojenského mapování. Podrobněji jsou webové mapové služby popsány např. v mé publikaci připravené na konferenci GICON 2006 ve Vídni [4].

\section{Závěr}

Myslím, že tento standardně popsaný postup pro publikování historických map na internetu umožní snadný převod dat v různých mapových archivech. Má práce podnítila budoucí vybavení Laboratoře digitální kartografie serverovým hardware (předpoklad v červnu 2006). Na tomto serveru pak budou aplikace veřejně přistupné. Kromě samotných aplikací budou data poskytována pomocí WMS a kdokoliv si tak bude moci připojit do své aplikace tato data. V souvislosti s mou prací bude do výuky na naší fakultě zaveden nový předmět Interaktivní kartografie, jehož náplní bude právě práce s mapovými servery.

Samotné internetové aplikace lze samozřejmě vylepšovat. Rád bych aplikace doplnil přepočty souřadnic do hojně využívaného WGS-84. Další možností je implementovat určování kladu mapových listů podle pohybu myši nad mapovým oknem. V oblasti zdrojových dat bude třeba georeferencovat i zbylé oblasti ČR (Morava, Slezsko). Velice zajímavé bude spojení těchto souřadnicových soustav do bezešvé mapy. Stejným postupem jako II. vojenské mapování bude možné zpracovat III. vojenské mapování. Otázkou zůstává georeferencování I. vojenského mapování, kde není možné použít rohů mapových listů. 


\section{Reference}

1. Cajthaml J.: Využití webových mapových serverů. Sborník: 16. kartografická konference - Mapa v informační společnosti, 7.-9.9.2005. Ed.: Václav Talhofer, Lucie Friedmannová, Alois Hoffman. Univerzita obrany, Brno, ČR, 2005. 91 stran (abstrakta), plné texty na CD. ISBN 80-7231-015-1.

2. Cajthaml J.: Mapserver of the Old Maps. In: Proceedings of International Symposium GIS Ostrava, 23.-25.1. 2006. VSB - Technical University of Ostrava, ISSN 1213-2454.

3. Cajthaml J.: Jak publikovat staré mapy na internetu? In: Juniorstav 2006, sborník konference, Díl 8, Geodézie a kartografie, Brno 25.1.2006. VUT v Brně, 2006, ISBN 80-214-3114-8.

4. Cajthaml J.: Old Maps Internet Presentation - Overview of Possibilities In: GICON 2006 - Geoinformation Connecting Societies, sborník konference v tisku, Vienna 10.14.7.2006. University of Vienna, 2006.

5. Doubrava P.: Zpracování rastrových mapových podkladů pro využití v oblasti aplikací GIS a katastru nemovitostí. Doktorská disertační práce, 156 stran. ČVUT v Praze, 2005.

6. oficiální webové stránky projektu UMN MapServer ${ }^{11}$

7. oficiální webové stránky projektu mscross ${ }^{12}$

8. oficiální webové stránky projektu PostgreSQL ${ }^{13}$

\footnotetext{
${ }^{11}$ http://mapserver.gis.umn.edu

${ }^{12}$ http://datacrossing.crs4.it/en_Documentation_mscross.html

${ }^{13}$ http: //www . postgresql.org
} 